\title{
RIVER REJUVENATION WITH THE AID OF GIS AND REMOTE SENSING FOR SAHIBI WATERSHED
}

\author{
M. Anul Haq \\ Associate Professor, NIIT University, Rajasthan, India. \\ P. C. Rishinandan Yoga \\ NIIT University, Rajasthan, India.
}

\begin{abstract}
Sahibi River is the ephemeral, seasonal river flowing through Rajasthan, Haryana and ends in Najafgarh drain in Delhi. But, it is facing drought for more than a decade due to Climate change, Irregular irrigation and improper Land use management around the Sahibi watershed. To solve this problem, construction of water structures can be helpful to trap the rainfall and increase the water table which will lead to the restoration of the Sahibi River.
\end{abstract}

Keywords - Sahibi, Watershed, GIS, Remote Sensing, Rejuvenation

\section{INTRODUCTION}

Water Scarcity has been a big issue to the modern civilization. To overcome this problem requires efficient use of location intelligence to hold the water resources. Collection and management of runoff will results in increasing water availability for domestic and agricultural use as well as the ecosystem. To effectively restore the river, we have used the Watershed of the Sahibi River. Watershed is the topographical area which have common drainage pattern and also called Catchment area. Water structures requires considering number of parameters for feasible storage of water. So, in this study, parameters such as Rainfall, Slope, Landuse/Cover, Ground water, Land Surface Temperature, Evapotranspiration, Soil, NDVI, NDWI and Distance from River were used to find the potential sites.

\section{METHODOLOGY}

\section{A. Study area selection}

Since the rejuvenation of Sahibi is primary objective, we chose Watershed of Sahibi as study area. Watershed and the River bank were extracted from DEM with the help of GeoHECHMS tool.

\section{B. Slope}

Slope plays a major role in finding potential locations for building water structures. Each type of structure such as Check Dams, Tanks, etc., requires different level from Gentle to Steep slopes. So, slope is identified with the help of
ASTER DEM data and with the help of ArcGIS Slope Analysis tool.

\section{Soil}

Soils are the foundation for choosing the appropriate sites. In this study, I have used Food and Agriculture Organization of the United Nations Soil data. It is important to analyze the infiltration and run-off properties of the Soil. So, we have reclassified the soil data into Hydrologic Soil Group (HSG) as Group A, B and C.

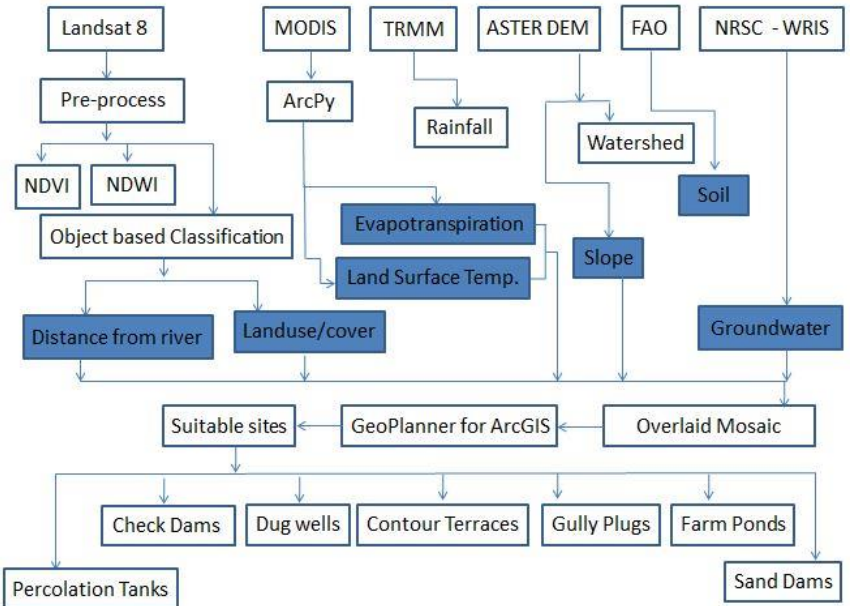

Fig. 1. Methodology diagram

\section{Landuse/cover}

Pre-processed data is classified using ENVI. we have adopted Object based cum Maximum Likelihood classification for discriminating different features of the Landsat data. On the course of choosing training sets, we faced difficulty in differentiating River from Fallow land class due to the drought and encroachment. So, we have extracted the features as objects with same spatial, spectral and radiometric properties with the help of Segmentation tool in ENVI and conducted the classification. 


\section{International Journal of Engineering Applied Sciences and Technology, 2020 \\ Vol. 5, Issue 8, ISSN No. 2455-2143, Pages 115-119 \\ Published Online December 2020 in IJEAST (http://www.ijeast.com)}

\section{E. Normalized Difference Vegetation and Water Index}

Vegetation and Water Index parameters were extracted with the help of Red, Green and Infrared bands of the Preprocessed Landsat data and applied the equation.

$$
\begin{aligned}
& N D V I=N I R-\text { Red } / N I R+\text { Red } \\
& N D W I=\text { Green }- \text { SWIR/Green }+ \text { SWIR }
\end{aligned}
$$

\section{F. Python based parameters}

ArcPy is ArcGIS module for python used for automation of tasks within the software. For parameters such as Evapotranspiration (ET), Land Surface Temperature (LST) and Rainfall, we need yearly average of Moderate Resolution Imaging Spectroradiometer (MODIS) and Tropical Rainfall Measuring Mission (TRMM) data for getting sufficient results for the analysis. In this process, we needed to extract near real time data (3-hr, 8-day, Monthly data). Extracting individually will be tedious. So, we have used ArcPy to automate the process and prepared a Script tool for ET and LST.

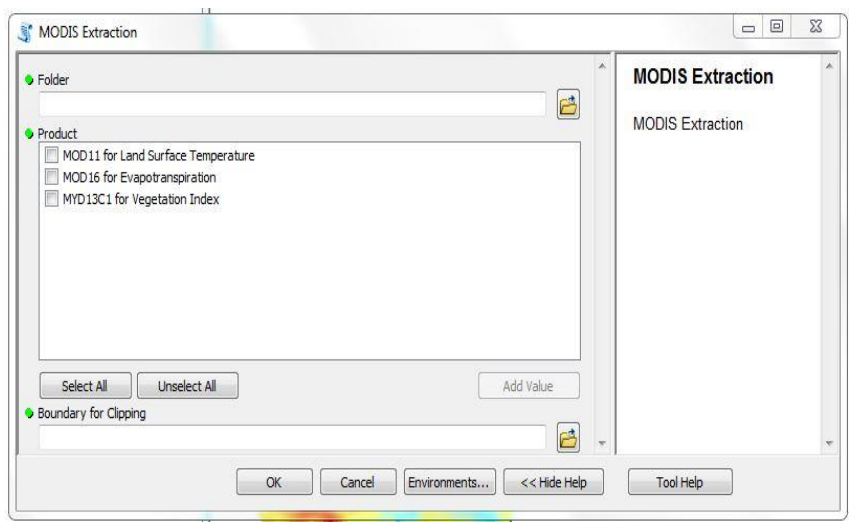

Fig. 2. ArcPy Tool

\section{G. Groundwater}

Ground water data is collected from the NRSC-WRIS portal for one year with classes such as monsoon, Pre-monsoon and Post-monsoon. These values were interpolated using IDW method and Average of one year is considered for further analysis.

\section{H. Distances from River}

Some of the water structures require being located near to the river for restoration. So, River bed extracted from the Geo-HecHMS tool is used and buffered to different distances with the help of multiple ring buffer tool.

\section{MOSAIC DATASET}

Mosaic data is used to create a single image contains multiple image parameters. These parameters were assigned with weights and metadata is generated with attribute information. The mosaic data is published online through ArcGIS Server and used to build Suitability models.

\section{A. Weighted Overlay service}

For configuring the mosaic dataset and assigning weights and labels Weighted overlay service tool is required. Configure raster field is used to assign the weights to different features based on their importance and feasibility of water structure. Then mosaic is built and published in portal. It is hosted as dynamic image service, so that can be used to process the images on-the fly.

\section{B. GeoPlanner}

GeoPlanner for ArcGIS is collaborative tool for designing and multiple scenario planning which leverages the Decision-making from geographic content. It consists of tools such as Explore, Design and Evaluate which supports a planning workflow from project creation to report generation. The Mosaic dataset consisting of parameters were accessed in this application using Modeler tool. The weights were assigned between $0-9$ range. Modeler tool has ability to assign the Layer weights and class weight dynamically. The design layers were prepared to predict the possible location and validate with the other layers such as Sub- watersheds.

\section{RESULTS \& DISCUSSION}

Thematic layers prepared are used as parameter and assigned weights based on their importance with respect to constructing water structures. Weighted Overlay method is adopted for this study. Generally, the values of continuous raster are grouped into common scale of values for

\begin{tabular}{|c|c|c|c|c|c|c|}
\hline Structure & Slope & $\begin{array}{l}\text { Rainfal } \\
\text { l }\end{array}$ & LULC & $\begin{array}{l}\text { Hydrolo } \\
\text { gic Soil } \\
\text { Group }\end{array}$ & $\begin{array}{l}\text { Gro } \\
\text { und } \\
\text { wate } \\
\mathbf{r}\end{array}$ & $\begin{array}{l}\text { Dist. } \\
\text { from } \\
\text { River } \\
\text { (Mete } \\
\text { r) }\end{array}$ \\
\hline $\begin{array}{l}\text { Percolatio } \\
\text { n Tanks }\end{array}$ & Gentle & High & $\begin{array}{l}\text { Barren } \\
\text { land } \\
\text { Fallow } \\
\text { land }\end{array}$ & A & High & $\begin{array}{l}500 \\
1000 \\
1500\end{array}$ \\
\hline $\begin{array}{l}\text { Check } \\
\text { dams }\end{array}$ & $\begin{array}{l}\text { Mediu } \\
\text { m to } \\
\text { Gentle }\end{array}$ & High & $\begin{array}{l}\text { River } \\
\text { Bed } \\
\text { Barren } \\
\text { land } \\
\text { Fallow } \\
\text { land }\end{array}$ & $\begin{array}{l}\text { A } \\
\text { B }\end{array}$ & $\begin{array}{l}\text { High } \\
\text { Med } \\
\text { ium }\end{array}$ & $\begin{array}{l}500 \\
1000\end{array}$ \\
\hline $\begin{array}{l}\text { Farm } \\
\text { ponds }\end{array}$ & Gentle & High & $\begin{array}{l}\text { River } \\
\text { bed } \\
\text { Fallow } \\
\text { land } \\
\text { Crop } \\
\text { land }\end{array}$ & A & $\begin{array}{l}\text { High } \\
\text { Med } \\
\text { ium }\end{array}$ & $\begin{array}{l}500 \\
1000 \\
1500\end{array}$ \\
\hline Dug wells & Gentle & $\begin{array}{l}\text { High } \\
\text { Mediu } \\
\text { m }\end{array}$ & $\begin{array}{l}\text { Barren } \\
\text { land } \\
\text { Fallow } \\
\text { land }\end{array}$ & $\begin{array}{l}\text { A } \\
\text { B }\end{array}$ & High & $\begin{array}{l}500 \\
1000\end{array}$ \\
\hline
\end{tabular}
parameters such as slope, groundwater level, etc., 
International Journal of Engineering Applied Sciences and Technology, 2020

Vol. 5, Issue 8, ISSN No. 2455-2143, Pages 115-119

Published Online December 2020 in IJEAST (http://www.ijeast.com)

\begin{tabular}{|l|l|l|l|l|l|l|}
\hline $\begin{array}{l}\text { Sand } \\
\text { dams }\end{array}$ & Gentle & $\begin{array}{l}\text { High } \\
\text { Mediu } \\
\mathrm{m}\end{array}$ & $\begin{array}{l}\text { River } \\
\text { bed } \\
\text { Fallow } \\
\text { land } \\
\text { Barren } \\
\text { land }\end{array}$ & A & $\begin{array}{l}\text { Med } \\
\text { ium }\end{array}$ & 500 \\
\hline $\begin{array}{l}\text { Contour } \\
\text { terraces }\end{array}$ & $\begin{array}{l}\text { Steep } \\
\text { to } \\
\text { Mediu } \\
\text { m }\end{array}$ & $\begin{array}{l}\text { Mediu } \\
\text { m }\end{array}$ & $\begin{array}{l}\text { Barren } \\
\text { land } \\
\text { Forest }\end{array}$ & C & $\begin{array}{l}\text { Med } \\
\text { ium }\end{array}$ & $>1500$ \\
\hline $\begin{array}{l}\text { Gully } \\
\text { plugs }\end{array}$ & Gentle & High & $\begin{array}{l}\text { River } \\
\text { bed }\end{array}$ & A & B High & 500 \\
\hline $\begin{array}{l}\text { Layer } \\
\text { Weight } \%\end{array}$ & 25 & 20 & 20 & 15 & 10 & 10 \\
\hline
\end{tabular}

TABLE I. Criteria for finding sites for water structures

The combination of different thematic layers helps to obtain best location for water structures and GIS helps to scientifically identify the location.

\section{A. Parameters}

Numbers of parameters were prepared with the help of satellite data and GIS. Integrated parameters can be used to identify the potential zones based on the requirement.

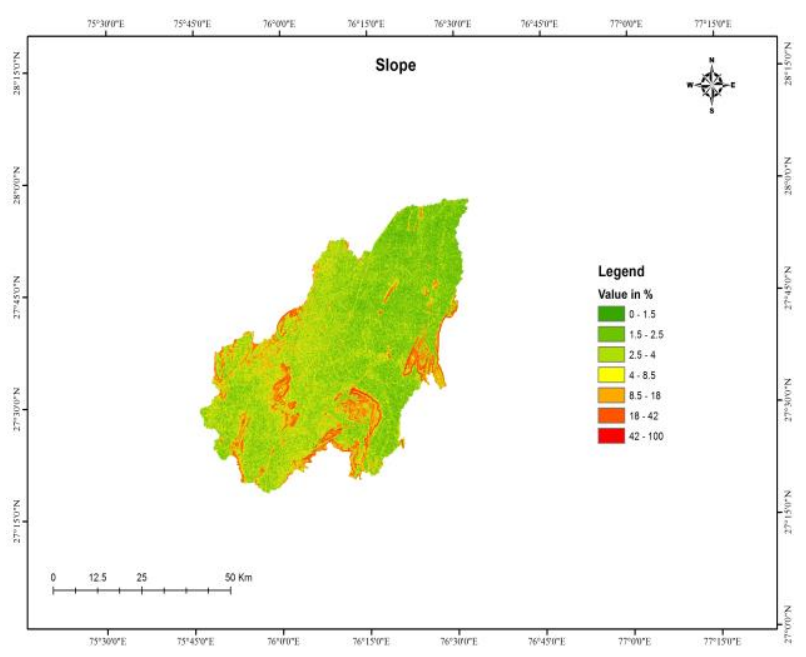

Fig. 3. Slope

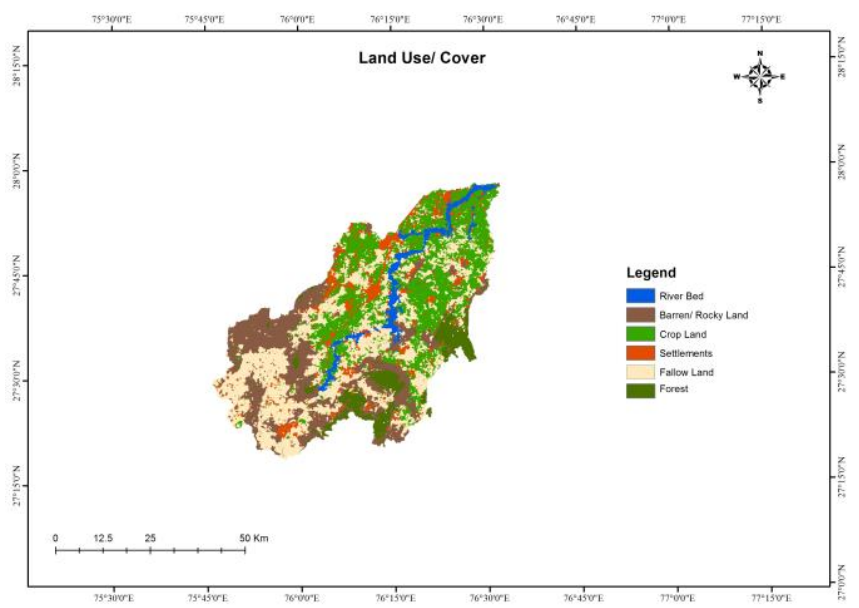

Fig. 4. Land Use/Cover

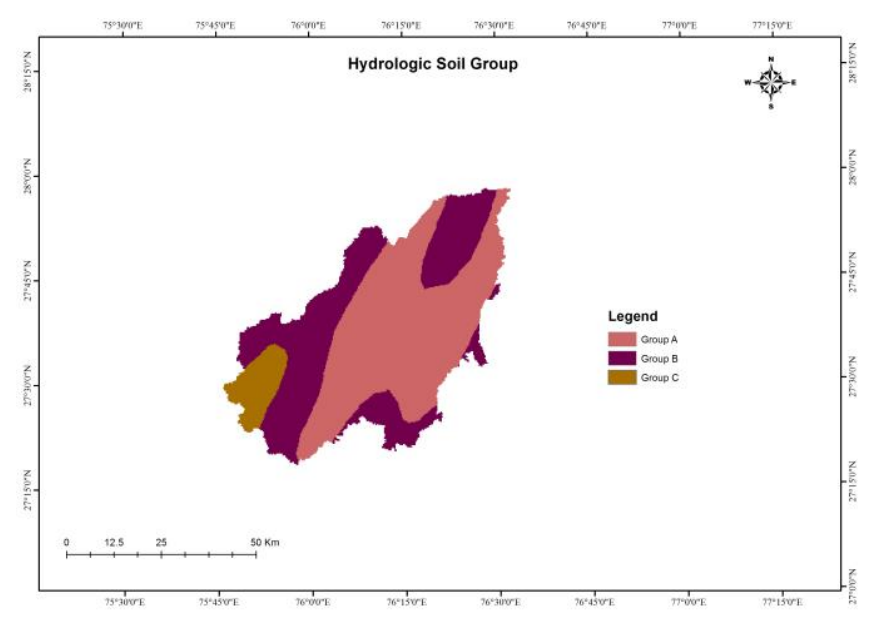

Fig. 5. Hydrologic Soil Group

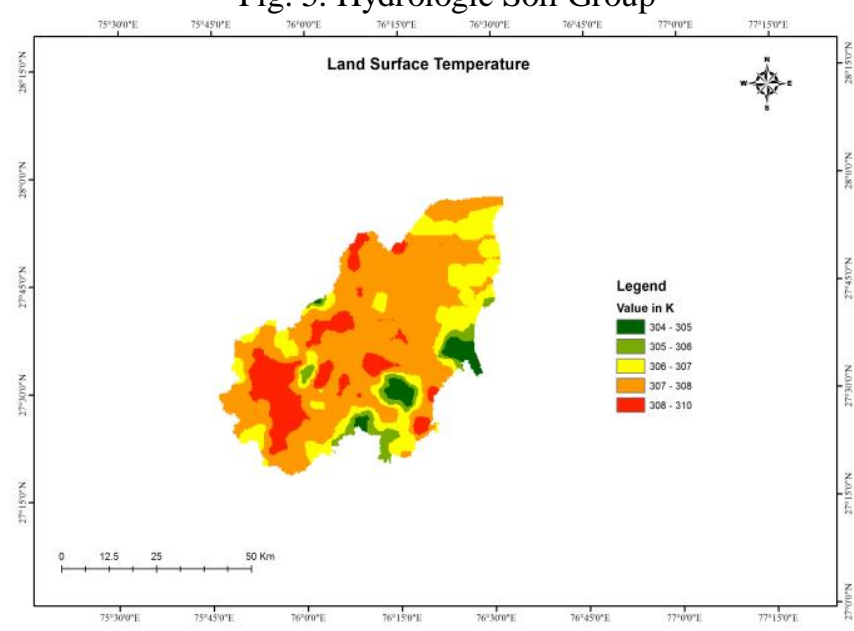

Fig. 6. Land Surface Temperature

Different parameters were assigned with unique weights based on the type of water structure involved. For instance, Contour terraces are the structures which require higher elevated regions. So, Steeper slope is given more weightage for finding the suitable location.

\section{B. Suitability models}

Based on the criteria table the suitability models were prepared for water structures such as Percolation Tanks, Check Dams, Contour Terraces, Gully Plugs, Farm Ponds, Dug-wells and Sand Dams. Each structure needs unique environment required for sustainable water supply, which were assessed using the different parameters.

a). Percolation tanks: It is an artificially created surface water body, submerging in its reservoir a highly permeable land so that surface runoff is made to percolate and recharge the ground water storage 


\section{International Journal of Engineering Applied Sciences and Technology, 2020 \\ Vol. 5, Issue 8, ISSN No. 2455-2143, Pages 115-119 \\ Published Online December 2020 in IJEAST (http://www.ijeast.com)}

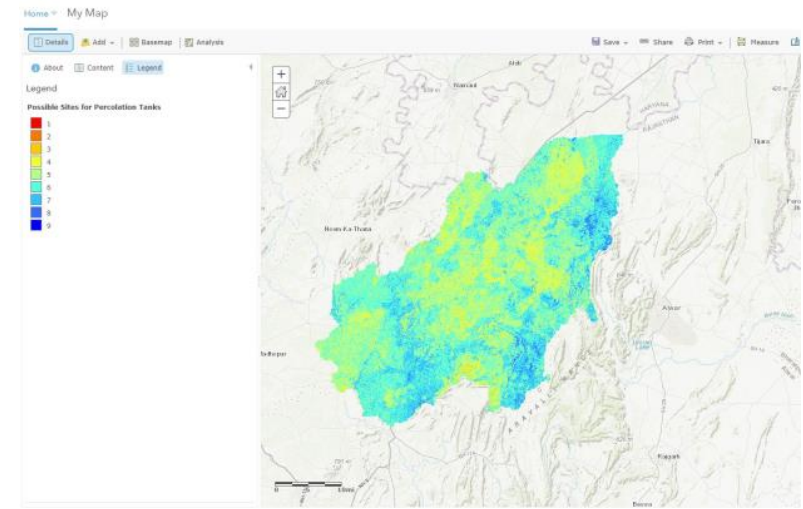

Fig. 7. Suitable sites for Percolation tanks

a) Check Dams/ Nala bunds: A check dams is a small barrier constructed of rock, gravel bags, sandbags, fiber rolls, or reusable products, placed across a constructed swale or drainage ditch.

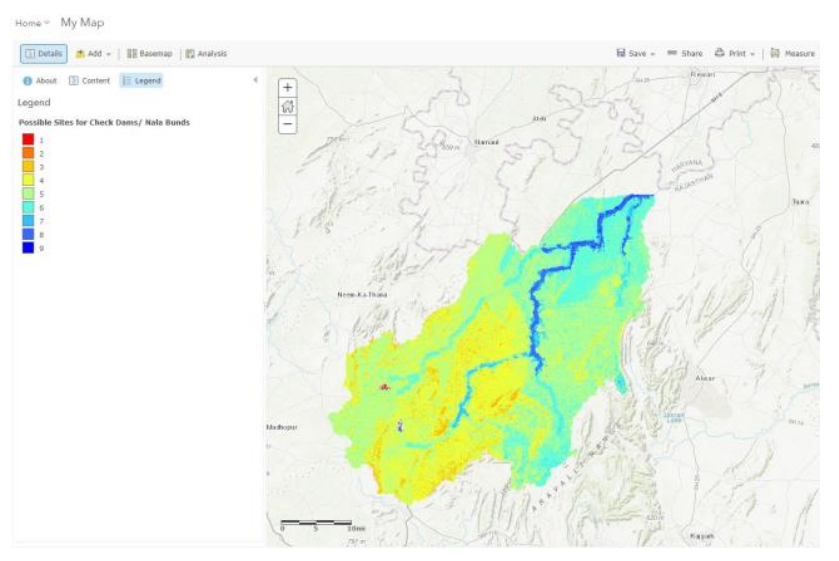

Fig. 8. Suitable sites for Check Dams

b) Farm ponds: It is constructed on the Gentle Slope Terrain which can hold the Rain water for Natural Ground water recharge with considerably smaller region.

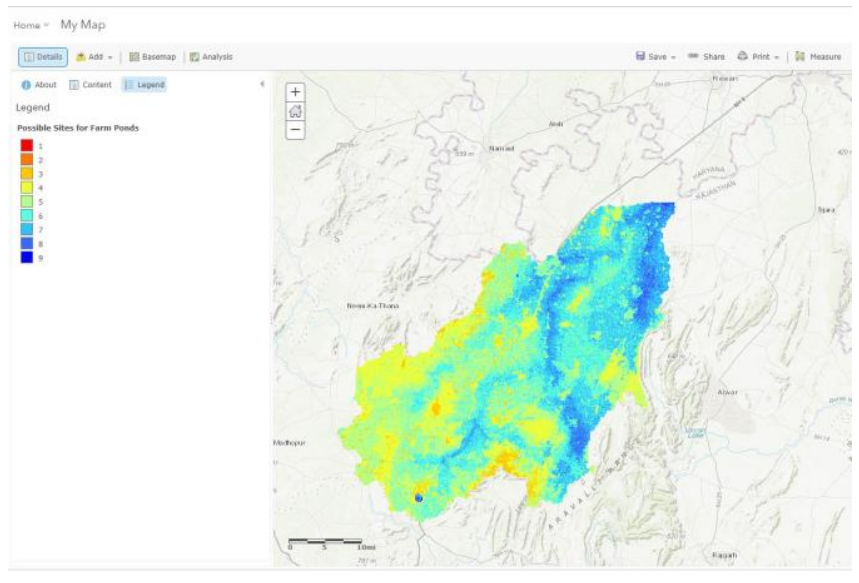

Fig. 9. Suitable sites for Farm ponds

c) Dug wells/ Cisterns: These are the hole like structures in the ground excavated below the groundwater table. In this study, we have given more importance to the locations near the river bed for the purpose of connection so that sustainable water flow can be achieved.
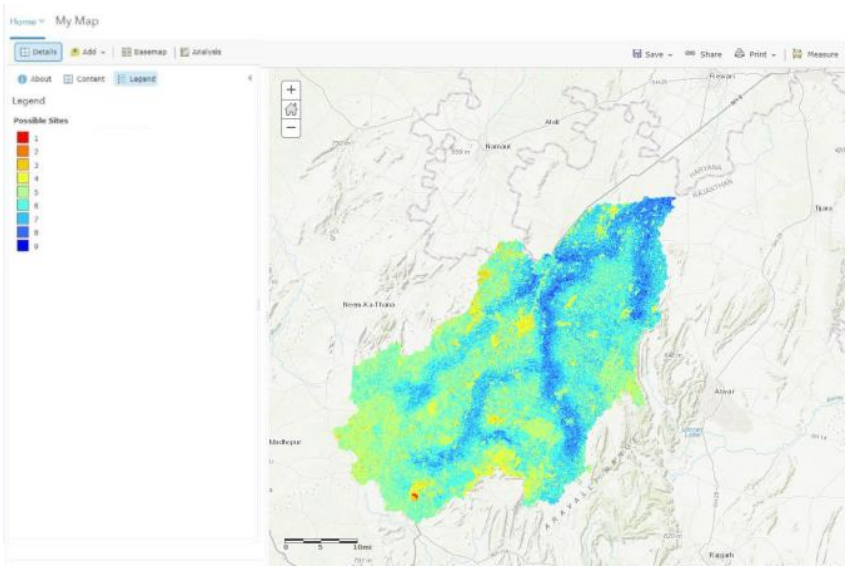

Fig. 10. Suitable sites for Dug wells

d) Gully Plugs: Small dam structures constructed across erosion gullies are small low structures built across a channel to hold the run-off water. It is observed to be cost effective structure consists of gravels and boulders allows to spill the water across the River bank.

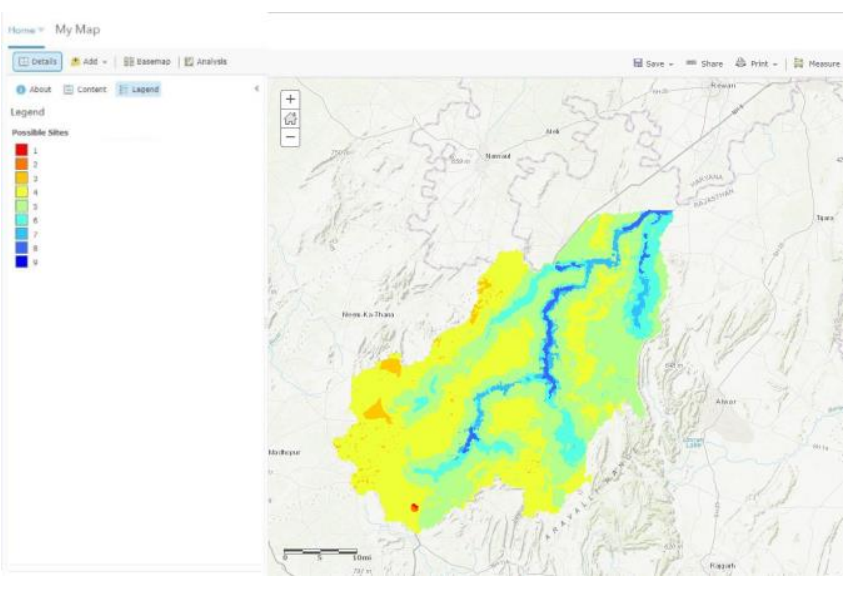

Fig. 11. Suitable sites for Gully plugs

e) Sand Dams/ Joheds: A sand dam is distinctive with the spillway being constructed at the Centre. The structure is designed to withhold sand from the flowing water. Taming the flow of water during the monsoons, it slows down the river so as to allow water to gradually percolate recharging sub-soil water, usually built in the edges of the River bank. 


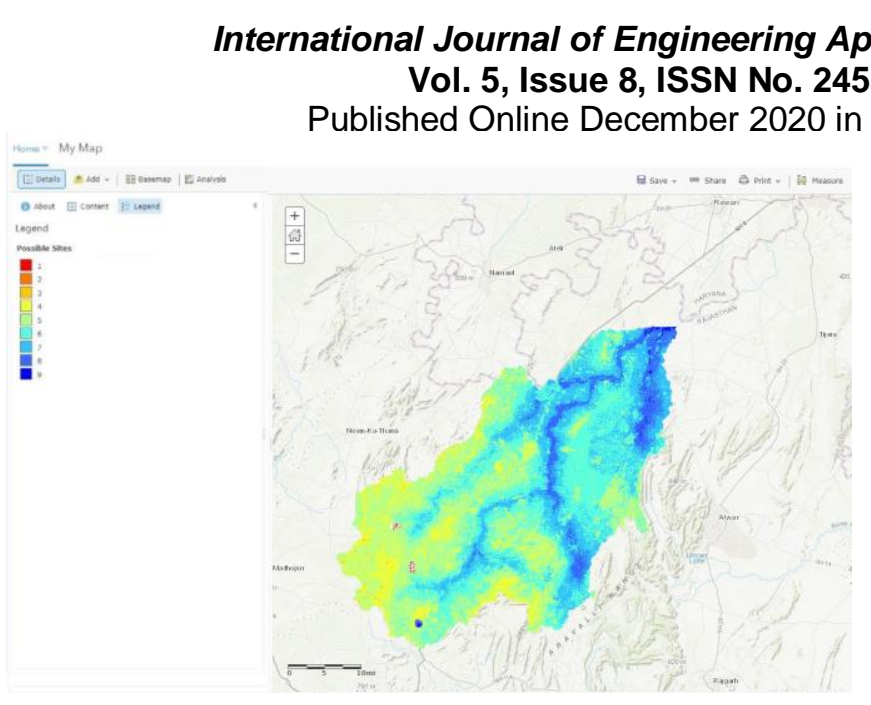

Fig. 12. Suitable sites for Sand Dams

f) Contour terraces: It is the practice of tilling sloped land along lines of consistent elevation in order to conserve rainwater and to reduce soil losses from surface erosion. Contour Terraces or Bench Terraces permits increased infiltration and more uniform distribution of the water and can be connected to the existing ponds or tanks to store the flowing water.
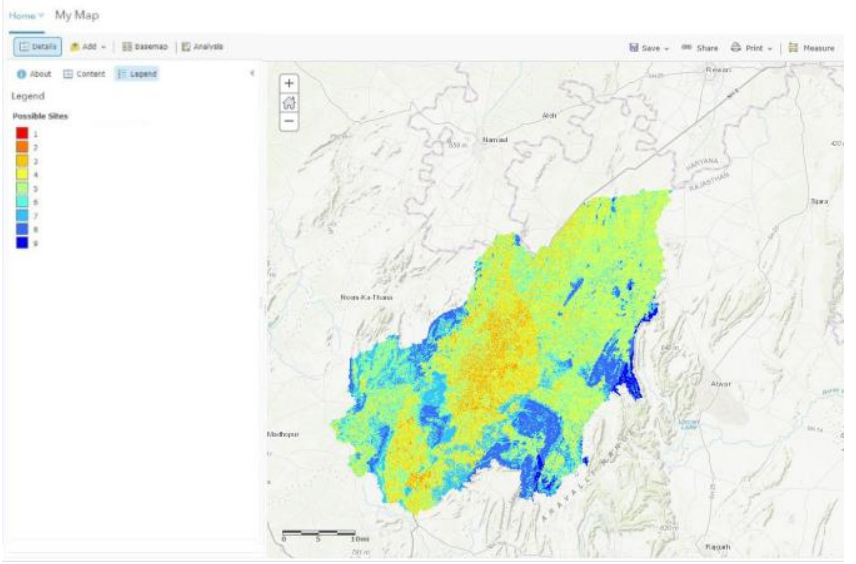

Fig. 13. Suitable sites for Contour terraces

\section{Evaluation of models}

Different models were evaluated by creating designs of structures and verified with layers such as Sub Watersheds, Existing structures and Scenarios through GeoPlanner for ArcGIS. Multiple scenario based analysis is made according to different structure such as Percolation tanks, Contour Terraces, etc. Additionally, Performance indicator is used to measure the performance based on the requirement. In this study, count of water structures given as indicator depends upon the cost factor.

\section{CONCLUSIONS}

Sahibi is having dendritic drainage pattern and at the end of monsoon, water scarcity starts and increases the demand. As large amount of water is exploited from the underground for irrigation which in turn reduces the Water level. Different parameters helped to effectively analyze the location patterns and mosaic dataset helped to combine the different information. ArcPy is used to automate the processing of satellite data and reduce the time.

The study showed us the importance of Geographic Information and tools to predict the potential locations for water structures. Most of the zones were found in the eastern and central part of the Watershed. Implementation of these models would gradually improve the Water table of this region and leads to the beneficiary for number of states in and around the Sahibi River. Collaborative analysis with stakeholders would reflect the potential of Sustainable Irrigation.

\section{REFERENCES}

[1] G Abdulla Umar Naseef T, Reeba Thomas. (2015). Identification of Suitable Sites for Water Harvesting Structures in Kecheri River Basin.

[2] G.W. Geerling, A.M.J. Ragas. (2006). Succession and rejuvenation in floodplains along the river Allier (France).

[3] Jorge A, Delgado, Rui Li. (2016). The Nanchang Communication about the potential for implementation of conservation for climate change mitigation and adaptation to achieve food security in the 21 st century.

[4] Patil, Shivraj G, Wayal, Abhaykumar S. (2013). Watershed management in Rural Area - Ralegoan Siddhi.

[5] S. M. Chintapalli, P. V. Raju, S. Jonna and K. Abdul Hakeem. (2000). Satellite Remote Sensing and GIS technologies to aid sustainable management of Indian irrigation systems..

[6] Sameer Shadeed, Jens Lange.(2010). Rainwater harvesting to alleviate water scarcity in dry conditions. Water Science and Engineering,

[7] Solomon Vimal, D Nagesh Kumar and Indhu Jaya. (2012). Extraction of Drainage Pattern from ASTER and SRTM Data for a River Basin using GIS Tools.

[8] S.K. Ambast, Ashok K. Keshari \& A.K. Gosain. (2002). Satellite Remote Sensing to support management of irrigation systems.

[9] Shashank Shekhar. (2016). Environmental flows and river rejuvenation, University of Delhi

[10] Jitendra Sinha, Manoj Kumar Sinha \& Umesh Rao Adapa. (2013). Flow - River Rejuvenation in India

[11] Faizal I.W. Rohmat, Timothy K. Gates, John W.Labadie. (2020). Enabling improved water and environmental management in an irrigated river basin using multi-agent optimization of reservoir operations

[12] S.R.Asolekar, P.P.Kalbar, M.K.M.Chaturvedi, K.Y.Maillacheruvu. (2013). Rejuvenation of Rivers and Lakes in India: Balancing Societal Priorities with Technological Possibilities. 